\title{
Productivity and crude protein concentration of Tifton 85 pasture-based mixed with pinto peanut
}

\section{Produtividade e proteína bruta de pastagens de Tifton 85 em consórcio com amendoim forrageiro}

\author{
Clair Jorge Olivo ${ }^{1 *} \mathbb{D}$, Mauricio Pase Quatrin ${ }^{1} \mathbb{D}$, Caroline Paim Sauter $\mathbb{B}^{\mathbb{D}}$, Aline Rodrigues Silva ${ }^{1} \mathbb{D}$, \\ Julio Clemente Sauthier ${ }^{1} \mathbb{D}$, Marcelo Paim Sauter ${ }^{1} \mathbb{D}$
}

\author{
${ }^{1}$ Universidade Federal de Santa Maria/UFSM, Department of Animal Science, Santa Maria, RS, Brasil \\ *Corresponding author: clairolivo@yahoo.com.br \\ Received in November 6, 2018 and approved in May 14, 2019
}

\begin{abstract}
Mixed pasture grass-legume systems balance forage supply and minimize environmental impacts by reducing the need for nitrogen fertilization. Pinto peanut (Arachis pintoi Krap. and Greg. "Amarillo") has several traits that are suitable for mixed pastures but have not yet been adequately explored. The aim of this study was to evaluate a mixture of Tifton 85 bermudagrass (Cynodon dactylon) and pinto peanut and evaluate forage yield, crude protein, and stocking density. A two-year study of three grazing systems was used with the following treatment combinations: (a) Tifton $85(T)+100 \mathrm{~kg} \mathrm{~N} \mathrm{ha-1} \mathrm{yr}^{-1}+$ pinto peanut $(T+P P+100) ;(b) T+100 \mathrm{~kg} \mathrm{~N} \mathrm{ha}^{-1} \mathrm{yr}^{-1}(\mathrm{~T}+100$; control, pure grass); and (c) T + $200 \mathrm{~kg} \mathrm{~N} \mathrm{ha}^{-1} \mathrm{yr}^{-1}$ ( $\mathrm{T}+200$; positive control, pure grass). In this study, forage yield, pasture characteristics and responses of lactating cows were evaluated. The experimental design was completely randomized with three treatments (grazing systems), three replicates (paddocks), and repeated measures (grazing cycles within seasons). Forage accumulation, crude protein concentration, and stocking rate were $15.1 ; 11.3$ and 14.1 t DM ha-1 $^{-1} \mathrm{yr}^{-1} ; 17 \%, 16 \%$, and 17\%; and 5.3; 4.9 and $6.1 \mathrm{AU}^{\text {ha-1 }}$ day $^{-1}$, respectively. The grass-legume system yielded the best results.
\end{abstract}

Index terms: Arachis pintoi; Cynodon dactylon; forage yield; grass-legume; Lolium multiflorum.

\begin{abstract}
RESUMO
Sistemas forrageiros constituídos pelo consórcio gramínea-leguminosa equilibram a oferta de forragem e minimizam impactos ambientais, pela redução da fertilização nitrogenada. O amendoim forrageiro tem várias características que são adequadas aos consórcios forrageiros, mas ainda não foram adequadamente explorados. O objetivo deste trabalho foi avaliar o consórcio constituído por capim bermuda, cv. Tifton 85, e o amendoim forrageiro quanto à produção de forragem, proteína bruta e taxa de lotação. Em dois anos agrícolas, foram avaliados três sistemas forrageiros assim constituídos: (a) Tifton $85(\mathrm{~T})+100 \mathrm{~kg} \mathrm{de} \mathrm{N} \mathrm{ha}^{-1} \mathrm{ano}^{-1}+$ amendoim forrageiro $(\mathrm{T}+\mathrm{AF}+100)$; (b) $\mathrm{T}+100 \mathrm{~kg}$ de N ha-1 $\mathrm{ano}^{-1}$ ( $\mathrm{T}+100$; controle, somente gramínea); e (c) $\mathrm{T}+200 \mathrm{~kg} \mathrm{de} \mathrm{N} \mathrm{ha-1}^{\mathrm{ano}-1}$ ( $\mathrm{T}+200$; controle positivo, somente gramínea). Neste estudo foram avaliados o rendimento de forragem, características da pastagem e respostas das vacas em lactação. O delineamento experimental foi o inteiramente casualizado com três tratamentos (sistemas forrageiros) e três repetições (piquetes) e medidas repetidas (ciclos de pastejo dentro das estações do ano). O acúmulo de forragem, a concentração de proteína e a taxa de lotação foram de 15,1; 11,3 e 14,1 t de MS ha-1 ano-1; 17\%, 16\% e 17\%; e 5,3; 4,9 e 6,1 UA ha-1 dia- $^{-1}$, respectivamente. Melhores resultados foram obtidos no consórcio forrageiro.
\end{abstract}

Termos para indexação: Arachis pintoi; Cynodon dactylon; produção de forragem; consórcio gramínea-leguminosa; Lolium multiflorum.

\section{INTRODUCTION}

The bermudagrass cultivar Tifton 85 [Cynodon dactylon (L.) Pers. $\times$ C. transvaalensis Burtt Davy] has high forage yield, good nutritional value, and better animal performance than other varieties (Hill; Gates; Burton, 1993; Scaglia; Boland, 2014). Nitrogen fertilization increases forage accumulation and protein concentration in Tifton 85 (Carvalho et al., 2000) nevertheless, the increasing cost of nitrogen fertilizer may limit its use (Sollenberger, 2008). A good alternative to nitrogen fertilizer use is a mixed grass-legume pasture because legumes fix atmospheric nitrogen and promote nutrient recycling in the soil (Abdul-Baki et al., 2002; Nascimento, 2006). Legumes can, therefore, increase herbage yield 
and nutritive value, improve seasonal forage distribution (Ames et al., 2014), and decrease nitrogen fertilizer use, thereby reducing its adverse environmental impact (Olivo et al., 2017). Pinto peanut (Arachis pintoi Krap. and Greg.) adapts well to grazing and has high productivity and nutritive value (Olivo et al., 2017). It is also associated with superior animal performance (Lascano, 1994).

There may be a synergy between Tifton 85 pasture and pinto peanut. However, there are few studies on this mixture. Both are warm-season perennial species, but Tifton 85 is a competitive and productive grass that spreads rapidly by stolons and rhizomes. Consequently, it does not readily associate with other plant species. It is difficult to introduce the mixture of pinto peanut and Tifton 85 because the legume establishes very slowly (Abdul-Baki et al., 2002). One way to overcome this inequality is to increase the planted area of perennial legume in relation to that of grass (Ziech et al., 2016a, b). The legume should constitute $13-23 \%$ of the forage mass. This proportion ensures sustainability of the forage system (Cadisch; Schunke; Giller, 1994). The aim of this study was to evaluate the botanical composition, forage accumulation, protein concentration, and forage intake of a pinto peanut-Tifton 85 bermudagrass mixed pasture under grazing conditions over a two-year period.

\section{MATERIAL AND METHODS}

\section{Study site}

The experimental methods in the present study were approved by the Ethics Committee on Animal Experimentation of the Federal University of Santa Maria (Protocol No. 23081016073/2011-27; Authorization No.113/2011).

The trial was conducted in Santa Maria, RS, Brazil, at $29^{\circ} 43^{\prime} \mathrm{S}, 53^{\circ} 42^{\prime} \mathrm{W}$ and $95 \mathrm{~m}$ altitude. The soil is classified as a Hapludalf Paleudult (Soil Survey Staff, 2014). The climate is Cfa (humid subtropical), according to the Köppen classification (Kuinchtner; Buriol, 2001). The average daily temperature and monthly precipitation are $19.3{ }^{\circ} \mathrm{C}$ and $140 \mathrm{~mm}$, respectively. Similar average values were recorded during the experimental period (18.8 ${ }^{\circ} \mathrm{C}$ and $140 \mathrm{~mm}$, respectively).

A soil chemical analysis $(0-0.10 \mathrm{~m}$ depth $)$ was performed before the start of the experiment and revealed the following soil characteristics: pH 6.1 (1:1 soil, 0.01 $\mathrm{M} \mathrm{CaCl}_{2}$ suspension$)$; total acidity $=4.0 \mathrm{mmolc} \mathrm{dm}^{-3}(\mathrm{H}$ $+\mathrm{Al}) ; \mathrm{Ca}^{2+}, \mathrm{Mg}^{2+}$, and $\mathrm{K}^{+}=6.3$ mmolc dm ${ }^{-3}, 2.9$ mmolc $\mathrm{dm}^{-3}$, and 0.4 mmolc $\mathrm{dm}^{-3}$, respectively; P (Mehlich-1) $=42 \mathrm{mg} \mathrm{dm}^{-3}$; organic matter $=4 \%$; and clay $=20 \%$.
The trial was conducted from September 2014 to April 2017. The experimental area $\left(1,620 \mathrm{~m}^{2}\right)$ was divided into nine paddocks each with an area of $\sim 18 \mathrm{~m} \times 10 \mathrm{~m}$ each. Throughout the evaluation period, $60 \mathrm{~kg} \mathrm{ha}^{-1} \mathrm{yr}^{-1} \mathrm{P}_{2} \mathrm{O}_{5}$ and $60 \mathrm{~kg} \mathrm{ha}^{-1} \mathrm{yr}^{-1} \mathrm{~K}_{2} \mathrm{O}$ were applied, based on the soil analysis.

\section{Previous research and treatments}

The protocol followed for pasture establishment in September 2014 is the same as that reported for a previous study (Ziech et al., 2016a, b). In the pure grass stand, Tifton 85 pasture was established by planting seedlings $10 \mathrm{~cm}$ deep in rows $50 \mathrm{~cm}$ apart. In the mixed pasture, pinto peanut-Tifton 85 was established by planting seedlings $10 \mathrm{~cm}$ deep in rows $50 \mathrm{~cm}$ apart (25\% grass and $75 \%$ forage legume; one row of grass per three rows of legume). The evaluation period was from May 2015 to April 2017. In May 2015, annual ryegrass (Lolium multiflorum Lam.) "Ponteio" was overseeded in all paddocks at the rate of $40 \mathrm{~kg} \mathrm{ha}^{-1}$. Three forage systems were used as the treatments: (a) Tifton $85+100 \mathrm{~kg}$ nitrogen $(\mathrm{N}$ ) $\mathrm{ha}^{-1} \mathrm{yr}^{-1}+$ pinto peanut - PP $(\mathrm{T}+\mathrm{PP}$; treatment determined from a previous clipping evaluation; Ziech et al., 2016a, b; Ziech et al., 2015); (b) Tifton $85+100 \mathrm{~kg} \mathrm{ha}^{-1} \mathrm{yr}^{-1} \mathrm{~N}$ (T + 100; control, pure grass); and (c) Tifton $85+200 \mathrm{~kg} \mathrm{ha}^{-1} \mathrm{yr}^{-1}$ $\mathrm{N}(\mathrm{T}+200$; positive control, pure grass). Nitrogen, in the form of granulated urea, was applied in four side dressings.

\section{Grazing management}

A sward height of $25 \mathrm{~cm}$ was used as the criterion for the onset of grazing (Pereira et al., 2011b). The method adopted was rotational stocking with one day of paddock occupation. Thirteen lactating Holstein cows were used. They had an average weight of $530 \pm 78 \mathrm{~kg}$ and produced an average of $18.63 \pm 4.38 \mathrm{~kg}$ milk d $\mathrm{d}^{-1}$. The cows were milked twice daily and fed a supplement concentrate consisting of corn, soybean meal, rice meal, wheat meal, and a mineral-vitamin mix. The concentrate was administered after each milking at the rate of $0.9 \%$ BW d-1. The concentrate was $180 \mathrm{~g} \mathrm{~kg}^{-1} \mathrm{DM}$ crude protein and $754 \mathrm{~g} \mathrm{~kg}^{-1} \mathrm{DM}$ total digestible nutrients.

\section{Pasture and animal measurements}

Herbage mass was estimated before and after grazing and during each grazing cycle. Four $0.25-\mathrm{m}^{2}$ quadrats per paddock were clipped down to soil level. The samples were then composted within a plot, subsampled, separated to determine the botanical composition of the pasture and the morphological composition of Tifton 85, then forced-air oven-dried at $55^{\circ} \mathrm{C}$ to a constant weight. Forage accumulation in the first grazing cycle was taken as the pre- 
grazing forage mass. For subsequent grazing cycles, forage accumulation was calculated by subtracting the pre-grazing forage mass of the following cycle from the post-grazing forage mass of the previous cycle. The forage accumulation rate was the relation between the forage accumulation and the number of days between grazing events. Total annual forage accumulation was calculated by summing the forage accumulation rates of all grazing cycles. Stocking density (AU) was based on one-day grazing, and a forage offer of $6 \mathrm{~kg}$ dry matter (DM) per $100 \mathrm{~kg} \mathrm{BW}$. Stocking rate was calculated by dividing the stocking density by the length of the grazing cycle in days. Forage intake was reported as a percentage of body weight and obtained by dividing the amount of harvested forage (pre-grazing forage mass minus post-grazing forage mass) by the weight of the animals on the pasture. Grazing efficiency was determined by evaluating the percentage of pre-grazing forage mass removed from the pasture at each grazing event. In the second year, the management methodology and evaluation used in the first year were repeated.

Paddocks were grazed in a 34-day cycle (approximately one day of grazing followed by 33 days of rest). In the first year, starting in August 2015, eight and seven grazing cycles were conducted in the pure grass forage and mixed pasture systems, respectively. In the second year, starting in August 2016, eight grazing cycles were performed in each system. Data for variables related to pasture and animal responses were grouped by season.

Samples $(n=10)$ were collected by the hand plucking method at the start and end of each grazing cycle. The samples were dried, ground in a Wiley-type mill, and stored. The samples harvested per paddock at the beginning and end of each grazing cycle were pooled and grouped by cool-season (winter and spring) and warm-season (summer and autumn). Their crude protein concentrations were then determined. Total $\mathrm{N}$ was determined by the Kjeldahl method (AOAC, 2005).

\section{Experimental design and statistical analysis}

Two-year averages were considered in the statistical analysis. Data were grouped by season. The experimental design was completely randomized with three treatments (forage system), three replications (paddocks), and repeated measures (season). The statistical model used was Yijk $=\mathrm{m}$ $+\mathrm{Ti}+\mathrm{Rj}(\mathrm{Ti})+\mathrm{Gk}+(\mathrm{TG}) \mathrm{ik}+$ Eijk, where Yijk represents the dependent variables ( $\mathrm{i}$ is the treatment index (forage system), $\mathrm{j}$ is the repetition index (paddocks), and $\mathrm{k}$ is the grazing cycle index); $m$ is the average of all observations; Ti is the treatment effect; $\mathrm{Rj}$ (Ti) is the effect of repetition in treatments (error a); Gk is the effect of mean grazing cycle per season; (TG)ik is the interaction between the treatments and the grazing cycles; and Eijk is the residual experimental error (error b). The data were subjected to ANOVA with the PROC MIXED module in SAS v. 3.6 (SAS, Cary, NC. USA). Means were compared using Tukey's test at the 5\% error probability level.

\section{RESULTS AND DISCUSSION}

There were no significant differences between the three systems in terms of pre-grazing herbage mass in three out of four seasons (Table 1). The only observed difference $(p<0.05)$ was in the summer when the lowest pre-grazing herbage mass was measured for the $T+100$ pure grass system. No significant differences between seasons were observed. In winter and spring, there was relatively more ryegrass but less Tifton 85 . In this way, herbage availability was balanced.

The proportion of Tifton 85, a warm-season grass, was greater in summer and autumn than in winter and spring. However, its proportion remained elevated during the colder seasons because there were comparatively few frost events at the onset of winter. Pinto peanut predominated even in the coldest seasons. Therefore, despite frost and low temperatures, pinto peanut recovered quickly and maintained the same proportion within each pasture composition throughout all seasons. The average proportion of pinto peanut constituting the pre-grazing forage mass $(18 \%)$ was within the range considered adequate to maintain forage sustainability (13-23\%) (Cadisch; Schunke; Giller, 1994). Previous studies reported similar proportions using the same forage mixture in trials conducted under a clipping regime over two years (Ziech et al., 2016a, b). Therefore, cattle trampling had no influence on the proportion of pinto peanut in the pasture composition.

The proportion of ryegrass was high in winter and spring when the presence of Tifton 85 was reduced. The lowest significant $(p<0.05)$ percentage of ryegrass in the mixed pasture $(\mathrm{T}+\mathrm{PP})$ occurred during spring because legume was present in the pasture composition.

Nonplanted species included bermudagrass (Cynodon spp.), alexandergrass (Urochloa plantaginea (Link) Hitch.), sourgrass (Paspalum conjugatum Berg.), vaseygrass (Paspalum urvillei Steud.), and sedges (Cyperaceae spp.). Their proportions in the pastures were relatively low because of the strong response of Tifton 85 to $\mathrm{N}$ fertilization (Pontes et al., 2016). In this way, Tifton 85 displaced other grass species. Moreover, the increase in the fraction of dead material (green herbage) was commensurate with $\mathrm{N}$ supply. In relation to the other systems, the mixed pasture had an intermediate proportion of dead material. 
Table 1: Pre-grazing herbage mass and botanical and morphological compositions of three pasture based systems (PS).

\begin{tabular}{|c|c|c|c|c|c|c|c|}
\hline \multirow{2}{*}{ Items } & \multirow{2}{*}{ PS } & \multicolumn{4}{|c|}{ Seasons } & \multirow{2}{*}{ Mean } & \multirow{2}{*}{ CV (\%) } \\
\hline & & Winter & Spring & Summer & Autumn & & \\
\hline \multirow{3}{*}{$\begin{array}{l}\text { Pre-grazing herbage } \\
\left.\text { mass ( } \mathrm{h} \mathrm{ha}^{-1}\right)\end{array}$} & $T+P P+100$ & 3.3 & 3.5 & $3.4 a$ & 3.7 & 3.5 & \multirow{3}{*}{11.23} \\
\hline & $T+100$ & 3.2 & 3.2 & $3.1 \mathrm{~b}$ & 2.9 & 3.1 & \\
\hline & $T+200$ & 3.4 & 3.3 & $3.5 a$ & 3.3 & 3.4 & \\
\hline \multirow[t]{3}{*}{ CV (\%) } & - & 9.4 & 19.4 & 11.2 & 12.7 & - & - \\
\hline & \multicolumn{7}{|c|}{ Botanical composition (\%) } \\
\hline & $T+P P+100$ & $32.3 \mathrm{~B}$ & $39.0 \mathrm{Bb}$ & 69.0Ab & $62.9 \mathrm{Ab}$ & 50.8 & \multirow{3}{*}{14.90} \\
\hline \multirow[t]{2}{*}{ Tifton 85} & $T+100$ & $39.5 B$ & $49.2 \mathrm{Ba}$ & 76.0Aab & $80.1 \mathrm{Aa}$ & 61.2 & \\
\hline & $T+200$ & 38.7B & $53.6 \mathrm{Ba}$ & 80.7Aa & $76.6 \mathrm{Aa}$ & 62.4 & \\
\hline \multirow[t]{2}{*}{ CV (\%) } & - & 10.5 & 10.7 & 8.3 & 9.9 & - & - \\
\hline & $T+P P+100$ & $47.1 \mathrm{~A}$ & $31.6 \mathrm{Bb}$ & - & - & 40.4 & \\
\hline \multirow[t]{2}{*}{ Annual ryegrass } & $T+100$ & $49.5 \mathrm{~A}$ & 33.7Ba & - & - & 41.6 & 13.50 \\
\hline & $T+200$ & $49.3 \mathrm{~A}$ & $37.0 \mathrm{Ba}$ & - & - & 42.0 & \\
\hline \multirow[t]{2}{*}{ CV (\%) } & - & 6.36 & 14.04 & - & - & - & - \\
\hline & $T+P P+100$ & $13.62 B$ & $18.93 \mathrm{~A}$ & $17.90 \mathrm{~A}$ & $21.36 \mathrm{~A}$ & 17.95 & \\
\hline \multirow[t]{4}{*}{ Pinto Peanut } & $T+100$ & - & - & - & - & - & \\
\hline & $T+200$ & - & - & - & - & - & \\
\hline & - & & & & & & \\
\hline & $T+P P$ & $2.1 \mathrm{Ba}$ & $2.7 \mathrm{Bb}$ & $6.1 \mathrm{Ab}$ & $9.4 \mathrm{~A}$ & 5.1 & \\
\hline \multirow[t]{2}{*}{ Other species } & $T+100$ & $1.1 \mathrm{Bb}$ & $7.2 \mathrm{Aa}$ & $12.4 \mathrm{Aa}$ & $8.7 \mathrm{~B}$ & 7.3 & 19.30 \\
\hline & $T+200$ & $4.2 \mathrm{Ba}$ & $4.5 \mathrm{Bb}$ & $10.9 \mathrm{Ab}$ & $12.7 \mathrm{~A}$ & 8.1 & \\
\hline \multirow[t]{2}{*}{ CV (\%) } & - & 27.8 & 15.0 & 22.7 & 20.1 & - & - \\
\hline & $T+P P+100$ & $4.8 \mathrm{~A}$ & 7.6Aab & $6.9 \mathrm{Ab}$ & $6.2 \mathrm{Ab}$ & 6.4 & \\
\hline \multirow[t]{2}{*}{ Dead material } & $T+100$ & $9.8 \mathrm{~A}$ & $9.8 \mathrm{Aa}$ & $11.5 \mathrm{Aa}$ & 11.1Aa & 10.1 & 23.20 \\
\hline & $T+200$ & $7.7 \mathrm{~A}$ & $4.8 \mathrm{Ab}$ & $8.2 \mathrm{Ab}$ & $10.5 \mathrm{Aa}$ & 7.84 & \\
\hline \multirow[t]{3}{*}{ CV (\%) } & - & 17.60 & 15.01 & 14.16 & 19.70 & - & - \\
\hline & \multicolumn{7}{|c|}{ Tifton 85: morphological composition (\%) } \\
\hline & $T+P P+100$ & $57.5 \mathrm{~A}$ & $53.5 \mathrm{Ab}$ & $41.4 \mathrm{~B}$ & $42.9 \mathrm{~B}$ & 49.9 & \multirow{3}{*}{15.51} \\
\hline \multirow[t]{2}{*}{ Leaf blade } & $T+100$ & $59.6 \mathrm{~A}$ & $54.3 \mathrm{Ab}$ & 43.1B & $49.5 \mathrm{~A}$ & 51.7 & \\
\hline & $T+200$ & $62.6 \mathrm{~A}$ & 64.7Aa & $42.9 \mathrm{~B}$ & 46.9B & 53.3 & \\
\hline \multirow[t]{2}{*}{ CV (\%) } & - & 16.2 & 14.5 & 8.4 & 11.4 & & \\
\hline & $T+P P+100$ & $42.4 \mathrm{~B}$ & $46.4 \mathrm{Ba}$ & $58.5 \mathrm{~A}$ & $50.4 \mathrm{Ab}$ & 50.1 & \multirow{3}{*}{16.5} \\
\hline \multirow[t]{2}{*}{ Stem + sheath } & $T+100$ & $40.3 \mathrm{~B}$ & 47.7Ba & $56.8 \mathrm{~A}$ & $50.4 \mathrm{Ab}$ & 48.3 & \\
\hline & $T+200$ & $37.3 \mathrm{~B}$ & $35.2 \mathrm{Bb}$ & $57.0 \mathrm{~A}$ & 57.0Aa & 46.7 & \\
\hline CV (\%) & - & 24.2 & 19.7 & 6.2 & 9.9 & - & - \\
\hline
\end{tabular}

Means followed by capital letters in the rows and lowercase letters in the columns significantly differ $(p<0.05)$ according to Tukey 's test. $\mathrm{T}+\mathrm{PP}+100=$ Tifton 85 (T) mixed with pinto peanut and fertilized with $100 \mathrm{~kg} \mathrm{ha}^{-1} \mathrm{yr}^{-1} \mathrm{~N} ; \mathrm{T}+100=\mathrm{Tifton} 85$ fertilized with $100 \mathrm{~kg} \mathrm{ha}^{-1} \mathrm{yr}^{-1} \mathrm{~N} ; \mathrm{T}+200=$ Tifton 85 fertilized with $200 \mathrm{~kg} \mathrm{ha}^{-1} \mathrm{yr}^{-1} \mathrm{~N} ; \mathrm{CV}=$ coefficient of variation. 
In spring, there was a significant effect of $\mathrm{N}$ fertilization $(p<0.05)$ on the morphology of Tifton 85 . In pasture with the highest fertilizer level, Tifton 85 had higher leaf blade and lower stem + sheath proportions than the other systems. Tifton 85 responds to $\mathrm{N}$ fertilization by increasing its leaf blade biomass production (Barbero et al., 2009; Pontes et al., 2016). In this system in autumn, the proportion of stem + sheath was significantly higher $(p<0.05)$ in response to increased N supply. In summer and autumn, the proportion of leaf blades was lower but the stem + sheath biomass was higher because forage growth rates were comparatively greater at that time.

Grazing intervals were longer in winter than at other times (Table 2). In winter, ryegrass growth was late because it was overseeded, the soil was not disturbed, and Tifton 85 was present. During the other seasons, $\sim 30$-day grazing cycles sufficed to improve forage accumulation (Pereira, et al., 2011a) and favor forage persistence (Nascimento, 2006).

In spring and autumn, grazing periods were comparatively longer in the mixed pasture because legumes were present. Legumes grow more slowly than companion grass (Abdul-Baki et al., 2002) and delay grazing.

Forage accumulation rates were high even in winter because of the large proportion of Tifton 85 relative to that of ryegrass. In spring, a residual effect of pinto peanut was observed in the mixed pasture and the accumulation rate was similar to that of the $T+200$ pure grass system. Comparable results were obtained for autumn. This response is explained by the fact that nitrogen and other nutrients are released into the soil by the partial degradation of pinto peanut in cold and frost conditions (Abdul-Baki et al., 2002; Bordeleau; Prévost, 1994). A similar value for herbage yield was reported by Barbero et al. (2009) who evaluated a mixture of pinto peanut with bermudagrass $+100 \mathrm{~kg} \mathrm{ha}^{-1} \mathrm{~N}$ and obtained $15,000 \mathrm{~kg} \mathrm{ha}^{-1} \mathrm{DM}$.

Over two years, the T + PP system had a greater herbage accumulation rate $(p<0.05)$ than the $\mathrm{T}+100$ system even though both of them received $100 \mathrm{~kg} \mathrm{~N}$ $\mathrm{ha}^{-1}$ in every season except winter. Herbage yields were correlated with herbage accumulation rates and were similar among grazing cycle intervals. The highest herbage yields $(p<0.05)$ were measured for the mixed pasture $(T+P P)$ and $T+200$ pure grass systems. The recommended forage offer was adjusted to $6 \% \mathrm{BW}$ and remained at 5\% among forage systems. The $4 \%$ forage offer verified in winter was associated with the improvement of forage nutritive value by the ryegrass.
Nevertheless, intake did not increase in winter because, despite the high proportion of Tifton 85, it has a lower nutritive value than ryegrass. The presence of legume (grass-legume system) increased forage allowance ( $p<$ 0.05 ) in all seasons compared to those of the pure grass systems even though the same amount of $\mathrm{N}$ fertilizer was used in both cases (Table 2). The mixed pasture and the $\mathrm{T}+200$ pure grass systems were similar to each other in spring and autumn because the nutritive value of the pasture was increased at high $\mathrm{N}$ fertilizer levels (Barbero et al., 2010; Olivo et al., 2017). For this reason, these systems also had similar annual herbage yields among these systems.

Grazing efficiency in the mixed pasture system was equivalent to that for the $T+200$ pasture system. The average grazing efficiencies of these forage systems indicate balanced use with no forage intake limitations. This condition normally occurs when the grazing efficiency is $>50 \%$ (Delagarde et al., 2001). In contrast, the average grazing efficiency for the $\mathrm{T}+100$ pure grass system was only $\sim 35 \%$ because of the lower proportion of Tifton 85 and the greater fraction of dead material in spring and autumn (Table 1).

Stocking rates were similar for the mixed and the $T+200$ pasture systems in winter, summer, and autumn. Between autumn and winter, the stocking rates were equivalent among the various systems because the grazing cycles were longer and the herbage accumulation rates were lower at that time than in spring and summer. In those two seasons, the stocking rates were higher than the herbage accumulation rates. The average stocking rates obtained in the present study resemble those obtained in the same region using a similar methodology with pure Coastcross- 1 bermudagrass and mixed grasslegume pasture (Olivo et al., 2016).

Crude protein concentrations (Table 3) were similar among systems in winter. At that time there is a high proportion of ryegrass, and the proportion of Tifton 85 leaf blades is greater than it is in the other seasons (Table 1). In summer, the mixed pasture and $\mathrm{T}+200$ pure grass system had similar crude protein concentrations $(p<0.05)$. These were higher than that of the $\mathrm{T}+100$ pasture system, which received the lowest of all fertilizer levels. The presence of pinto peanut in the warmest seasons accounted for the similarity between summer and winter in terms of herbage protein concentration. As shown by Fioreli et al. (2018), a mixture of grasses (Tifton 85 or Coastcross) with pinto peanut reduced the fibrous compounds and increased the crude protein concentrations. 
Table 2: Plant and animal responses in three pasture-based systems (PS) in Santa Maria, RS, Brazil. Data represent means of a two-year trial period (2015-2017).

\begin{tabular}{|c|c|c|c|c|c|c|c|}
\hline \multirow{2}{*}{ PS } & \multicolumn{4}{|c|}{ Seasons } & \multirow{2}{*}{ Mean } & \multirow{2}{*}{ CV (\%) } & \multirow{2}{*}{ Total } \\
\hline & Winter & Spring & Summer & Autumn & & & \\
\hline \multicolumn{8}{|c|}{ Interval between grazing events (days) } \\
\hline$T+P P+100$ & $43 \mathrm{~A}$ & 34Ba & $26 C$ & 36Ba & 35 & & \\
\hline$T+100$ & $43 \mathrm{~A}$ & $28 \mathrm{Bb}$ & $25 C$ & $33 \mathrm{Bb}$ & 32 & 10.8 & \\
\hline$T+200$ & $44 \mathrm{~A}$ & $29 \mathrm{Bb}$ & $25 \mathrm{C}$ & $33 \mathrm{Bb}$ & 32 & & \\
\hline CV (\%) & 1.9 & 8.3 & 1.7 & 5.4 & - & - & \\
\hline \multicolumn{8}{|c|}{ Forage accumulation (kg ha-1 $\left.\mathrm{d}^{-1} \mathrm{DM}\right)$} \\
\hline$T+P P+100$ & 77B & $115 \mathrm{ABa}$ & $201 \mathrm{Aa}$ & 75Ba & 68 & & \\
\hline$T+100$ & $74 B$ & $75 \mathrm{Bb}$ & $152 A b$ & $66 \mathrm{Bb}$ & 53 & 20.1 & \\
\hline$T+200$ & $81 \mathrm{~B}$ & 117ABa & 180Aab & 79Ba & 64 & & \\
\hline CV (\%) & 10.2 & 10.9 & 13.2 & 18.8 & - & - & \\
\hline \multicolumn{8}{|c|}{ Herbage yield (kg ha-1 $\left.\mathrm{yr}^{-1} \mathrm{DM}\right)$} \\
\hline$T+P P+100$ & $3,300 \mathrm{AB}$ & $3,900 \mathrm{ABa}$ & $5,200 \mathrm{Aa}$ & $2,700 \mathrm{~B}$ & 3,800 & & $15,100 a$ \\
\hline$T+100$ & $3,200 A B$ & $2,100 \mathrm{ABb}$ & $3,800 \mathrm{Ab}$ & $2,200 B$ & 2,800 & 22.3 & $11,300 b$ \\
\hline$T+200$ & $3,600 \mathrm{~A}$ & $3,400 \mathrm{ABa}$ & $4,500 \mathrm{Aab}$ & $2,600 \mathrm{~B}$ & 3,500 & & $14,100 a$ \\
\hline CV (\%) & 8.7 & 12.5 & 18.3 & 18.2 & - & - & - \\
\hline \multicolumn{8}{|c|}{ Forage offer (kg DM $\left.100 \mathrm{~kg} \mathrm{BW}^{-1} \mathrm{~d}^{-1}\right)$} \\
\hline$T+P P+100$ & 4.6 & $5.2 a$ & 5.2 & $5.1 \mathrm{~b}$ & 5.0 & 9.3 & \\
\hline $\mathrm{T}+100$ & 3.9 & $4.1 \mathrm{~b}$ & 6.0 & $7.4 a$ & 5.4 & 10.3 & \\
\hline$T+200$ & 3.9 & $4.4 a b$ & 5.7 & $5.8 a b$ & 4.9 & 9.8 & \\
\hline CV (\%) & 11.8 & 11.53 & 11.51 & 10.66 & - & - & \\
\hline \multicolumn{8}{|c|}{ Forage allowance (\% BW) } \\
\hline$T+P P+100$ & $3.1 a$ & $2.4 a$ & $2.7 a$ & $2.5 a b$ & 2.7 & & \\
\hline$T+100$ & $1.9 \mathrm{~b}$ & $1.6 b$ & $1.7 \mathrm{~b}$ & $1.4 \mathrm{~b}$ & 1.7 & 12.0 & \\
\hline$T+200$ & $2.2 \mathrm{~b}$ & 1.9ab & $1.8 \mathrm{~b}$ & $2.7 a$ & 2.1 & & \\
\hline CV (\%) & 17.3 & 18.7 & 10.7 & 13.9 & - & - & \\
\hline \multicolumn{8}{|c|}{ Grazing efficiency (\%) } \\
\hline$T+P P+100$ & 66.7Aa & $47.2 \mathrm{Ba}$ & $52.5 \mathrm{Ba}$ & 39.7Bab & 51.5 & & \\
\hline$T+100$ & $42.5 \mathrm{Ab}$ & $37.1 \mathrm{Bb}$ & $34.6 \mathrm{Bb}$ & $25.8 \mathrm{Bb}$ & 35.0 & 13.9 & \\
\hline$T+200$ & $62.1 \mathrm{Aa}$ & 45.9Bab & 38.7Bab & $50.0 \mathrm{Ba}$ & 49.2 & & \\
\hline CV (\%) & 9.7 & 13.6 & 13.9 & 14.0 & - & - & \\
\hline \multicolumn{8}{|c|}{ Stocking rate $\left(\mathrm{AU} \mathrm{ha}^{-1}\right)$} \\
\hline$T+P P+100$ & 4.6Ba & 4.7Ab & 7.2Aa & 4.6Bab & 5.3 & & \\
\hline $\mathrm{T}+100$ & $5.0 \mathrm{Ba}$ & 5.5Aab & $6.0 \mathrm{Ab}$ & $3.0 \mathrm{Bb}$ & 4.9 & 14.6 & \\
\hline$T+200$ & $4.8 \mathrm{Ba}$ & $6.9 \mathrm{Aa}$ & 7.5Aa & $5.4 \mathrm{Ba}$ & 6.1 & & \\
\hline CV (\%) & 16.26 & 10.97 & 17.1 & 16.23 & - & - & \\
\hline
\end{tabular}

Means followed by capital letters in rows and lowercase letters in columns significantly differ $(p<0.05)$ according to Tukey's test. $\mathrm{T}+\mathrm{PP}+100=$ Tifton $85(\mathrm{~T})$ mixed with pinto peanut and fertilized with $100 \mathrm{~kg} \mathrm{ha}^{-1} \mathrm{yr}^{-1} \mathrm{~N} ; \mathrm{T}+100=$ Tifton 85 fertilized with 100 $\mathrm{kg} \mathrm{ha}^{-1} \mathrm{yr}^{-1} \mathrm{~N} ; \mathrm{T}+200=$ Tifton 85 fertilized with $200 \mathrm{~kg} \mathrm{ha}^{-1} \mathrm{yr}^{-1} \mathrm{~N} ; \mathrm{DM}=$ dry matter; BW = body weight; $\mathrm{AU}=$ animal unit (450 kg $\mathrm{BW}) ; \mathrm{CV}=$ coefficient of variation. 
Table 3: Crude forage protein concentrations in three pasture-based systems (PS) in Santa Maria, RS, Brazil (2015-2017). Forage samples were collected by the hand plucking method.

\begin{tabular}{ccccc}
\hline PS & Cool-season Warm-season & Mean CV (\%) \\
\hline \multicolumn{5}{c}{ Crude Protein (\%) } \\
\hline T+PP+100 & $16.8 \mathrm{~A}$ & $17.3 \mathrm{Aa}$ & 17.1 & 5.40 \\
$\mathrm{~T}+100$ & $17.5 \mathrm{~A}$ & $14.1 \mathrm{Bb}$ & 15.8 & 2.67 \\
$\mathrm{~T}+200$ & $17.8 \mathrm{~A}$ & $16.8 \mathrm{Ba}$ & 17.3 & 4.37 \\
Mean & 17.4 & 16.1 & 16.7 & - \\
$\mathrm{CV}(\%)$ & 3.48 & 4.82 & - & - \\
\hline
\end{tabular}

Means followed by capital letters on rows and lowercase letters in columns significantly differ $(p<0.05)$ according to Tukey's test. $T+P P+100=$ Tifton $85(T)$ mixed with pinto peanut and fertilized with $100 \mathrm{~kg} \mathrm{ha}^{-1} \mathrm{yr}^{-1} \mathrm{~N} ; \mathrm{T}+100=$ Tifton 85 fertilized with $100 \mathrm{~kg} \mathrm{ha}^{-1} \mathrm{yr}^{-1} \mathrm{~N} ; \mathrm{T}+200=$ Tifton 85 fertilized with $200 \mathrm{~kg}$ $\mathrm{ha}^{-1} \mathrm{yr}^{-1} \mathrm{~N} ; \mathrm{CV}=$ coefficient of variation. The cool-season was characterized by the presence of ryegrass. Its contributions to the forage mass were $41.6 \%, 42.1 \%$ and $40.5 \%$ for the respective forage systems.

\section{CONCLUSIONS}

The evaluation of mixed pasture comprising pinto peanut and Tifton 85 , planted on $75 \%$ and $25 \%$ of the planting area, respectively, demonstrated that the proportion of forage legume in the pasture composition over two years was similar to that of mixed pasture under clipping evaluation. The pinto peanut-Tifton 85 , fertilized with $100 \mathrm{~kg} \mathrm{ha}^{-1} \mathrm{yr}^{-1} \mathrm{~N}$, and the Tifton $85+200 \mathrm{~kg} \mathrm{ha}^{-1} \mathrm{yr}^{-1} \mathrm{~N}$ are associated with the best results for both plant and animal responses. This therefore implies an economy of $100 \mathrm{~kg} \mathrm{ha}^{-1}$ year $^{-1}$ in $\mathrm{N}$ fertilization by using the pinto peanut mixed pasture system. The better results were found in the grass-legume system.

\section{REFERENCES}

ABDUL-BAKI, A. A. et al. Propagation and establishment of perennial peanuts for ground covers along roadsides and highway ramps. Proceedings of the Florida State Horticultural Society, 115(1):267-272, 2002.

AMES, J. P. et al. Dry matter production, chemical composition, dry matter digestibility and occurrence of fungi in bermudagrass hay (Cynodon dactylon) under different fertilization systems or associated with pea plantings in winter. Ciencia e Investigación Agraria, 41(2):163-174, 2014.

ASSOCIATION OF OFFICIAL ANALYTICAL CHEMISTS - AOAC. Official Methods of Analysis of the AOAC. 18ed. AOAC International, Gaithersburg, MD, USA, 2005.
BARBERO, L. M. et al. Produção de forragem e componentes morfológicos em pastagem de coastcross consorciada com amendoim forrageiro. Revista Brasileira de Zootecnia, 38(5):788-795, 2009.

BARBERO, L. M. et al. Produção animal e valor nutritivo da forragem de pastagem de coastcross consorciada com amendoim forrageiro. Arquivo Brasileiro de Medicina Veterinária e Zootecnia, 62(3):645-653, 2010.

BORDELEAU, L. M.; PRÉVOST, D. Nodulation and nitrogen fixation in extreme environments. Plant and Soil, 161(1):115-125, 1994.

CADISCH, G.; SCHUNKE, R. M.; GILLER, K. E. Nitrogen cycling in a pure grass pasture and a grass-legume mixture on a red latosol in Brazil. Tropical Grasslands, 28(1):43-52, 1994.

CARVALHO, C. A. B. de. et al. Tiller demography and dry matter accumulation rates in 'Tifton 85 ' swards under grazing. Scientia Agricola, 57(4):591-600, 2000.

DELAGARDE, R. et al. Ingestion de l'herbe par les ruminants au pâturage. Fourrages, 166(1):189-212, 2001.

FIORELI, A. B. et al. Valor nutritivo de gramíneas do gênero Cynodon consorciadas com amendoim forrageiro. Arquivo Brasileiro de Medicina Veterinária e Zootecnia, 70(6):1970-1978, 2018.

HILL, G. M.; GATES, R. N.; BURTON, G. W. Forage quality and grazing steer performance from Tifton 85 and Tifton 78 bermudagrass pastures. Journal of Animal Science, 71(12):3219-3225, 1993.

KUINCHTNER, A.; BURIOL, G. A. The climate of Rio Grande do Sul state according to Köppen and Thornthwaite classification. Disciplinarum Scientia, 2(1):171-182, 2001.

LASCANO, C. E. Nutritive value and animal production of forage Arachis. In: KERRIDGE, P. C.; HARDY, B. Biology and Agronomy of Forage Arachis. CIAT, Cali, CO, 1994, p.109-121.

NASCIMENTO, I. S. Perennial peanut cultivation. Revista Brasileira de Agrociência, 12(1):387-393, 2006.

OLIVO, C. J. et al. Forage systems mixed with forage legumes grazed by lactating cows. Acta Scientiarum: Animal Sciences, 39(1):19-26, 2017.

OLIVO, C. J. et al. Forage mass and nutritive value of bermuda grass mixed to pinto peanut or common vetch. Acta Scientiarum: Animal Sciences, 38(3):255-260, 2016.

PEREIRA, O. G. et al. Análise de crescimento do capim Coastcross-1 sob adubação nitrogenada em duas idades de rebrotação. Revista Brasileira de Zootecnia, 40(10):21212128, 2011 a. 
PEREIRA, O. G. et al. Morphogenic and structural characteristics of Tifton 85 bermudagrass under different nitrogen doses and harvesting heights. Brazilian Journal of Zootecnia, 40(9):1870-1878, 2011b.

PONTES, L. S. da. et al. Effects of nitrogen fertilization and cutting intensity on the agronomic performance of warmseason grasses. Grass and Forage Science, 72(1):663675,2016

SCAGLIA, G.; BOLAND, H. T. The effect of bermudagrass hybrid on forage characteristics, animal performance, and grazing behavior of beef steers. Journal of Animal Science, 92(3):1228-1238, 2014.

SOIL SURVEY STAFF. Keys to Soil Taxonomy. 12ed. USDA-Natural Resources Conservation Service, Washington, DC, USA, 2014. Available in: <https://www.nrcs.usda.gov/wps/portal/nrcs/ detail/soils/survey/class/taxonomy/?cid=nrcs142p2_053580>. Access in: May 31, 2019.

SOLLENBERGER, L. E. Sustainable production systems for Cynodon species in the subtropics and tropics. Revista Brasileira de Zootecnia, 37(1):85-100, 2008.

ZIECH, M. F. et al. Responses of Cynodon pastures mixed with pinto peanut in Southwestern Paraná, Brazil. Semina: Ciências Agrárias, 37(6):4193-4202, 2016b.

ZIECH, M. F. et al. Nutritive value of pastures of Cynodon mixed with pinto peanut in southwestern Paraná State. Acta Scientiarum. Animal Sciences, 37(3):243-249, 2015.

ZIECH. M. F. et al. Morphogenesis in pastures of Coastcross-1 and Tifton 85 mixed with pinto peanut, submitted to cutting management. Semina: Ciências Agrárias, 37(3):1461-1474, $2016 a$. 